\title{
SISTEM PENDUKUNG KEPUTUSAN INSENTIF KOMPENSASI BERDASARKAN KINERJA KARYAWAN DENGAN METODE WEIGHTED PRODUCT DI PT O07 GROUP
}

\author{
Amirul Aziz ${ }^{1)}$, Harunur Rosyid ${ }^{2}$ \\ ${ }^{1,2)}$ Teknik Informatika Universitas Muhammadiyah Gresik \\ Jl. Sumatra 101 Gresik Kota Baru (GKB), Randuagung, 61121Telp.(031) 3951414 , Faks. (0561) 740186 \\ E-mail: rulyaziz@gmail.com ${ }^{1)}$
}

\begin{abstract}
ABSTRAK
Kemajuan teknologi komputer yang begitu cepat memiliki posisi strategis sebagai pusat data dan informasi serta pusat kegiatan administrasi. Proses penentuan gaji berdasarkan kinerja pegawai sering kali terjadi kendala karena kurangnya informasi tentang kinerja pegawai. Untuk itu dalam skripsi ini, pembuatan aplikasi penggajian berbasis kinerja di PT 007 GROUP menggunakan metode Weightied Product dapat membantu menentukan pemilihan bonus pegawai berdasarkan kriterianya dengan menggunakan model perhitungan Weighted Product.

Hasil penilaian setiap kriteria karyawan dengan nilai tertinggi dapat dijadikan masukan bagi pihak administrasi dalam mengambil keputusan rekomendasi pemilihan bonus karyawan di PT. 007 Group.
\end{abstract}

Kata Kunci : Sistem Pendukung Keputusan, Weighted Product

\section{PENDAhuluan}

Pengertian gaji adalah pembayaran atau penyerahan jasa yang dilakukan oleh karyawan yang mempunyai jenjang jabatan manajer, sedangkan upah umumnya merupakan pembayaran atas penyerahan jasa yang dilakukan oleh karyawan pelaksana (buruh). Umumnya gaji dibayarkan secara tetap perbulan, sedangkan upah dibayarkan berdasarkan hari kerja, jam kerja atau jumlah satuan produk yang dihasilkan.

Permasalahan yang timbul dalam perusahaan selama ini adalah kurangnya metode untuk menentukan jumlah besaran gaji dan kurangnya efisien untuk menghitung besaran gaji. Belum adanya sebuah sistem penggajian yang diterapkan di perusahaan untuk menentukan jumlah besaran gaji berdasarkan kinerja karyawan, akibatnya pengolahan data gaji menggunakan perhitungan manual di excel. Untuk itu diperlukan suatu Sistem Pendukung Keputusan (SPK) yang dapat memperhitungkan segala kriteria yang digunakan.
Sehingga alokasi gaji untuk karyawan relevan dengan kinerja kayawan dalam suatu perusahaan. Pada dasarnya SPK merupakan pengembangan lebih lanjut dari Sistem Informasi Manajemen terkomputerisasi yang dirancang sedemikian rupa sehingga bersifat interaktif dengan pemakainya. Metode yang di pakai dalam pengambilan keputusan besaran gaji yang diberikan perusahaan merupakan suatu keputusan yang didasarkan pada konsep besaran gaji yang relevan dengan kinerja karyawan dalam perusahaan.

Sistem pendukung keputusan (SPK) pemilihan penerima bonus karyawan diselesaikan dengan mengunakan metode Weighted Product (WP). Metode yang dipilih adalah metode Wighted Product karena seleksi pemilihan penerima bonus karyawan digolongkan ke dalam masalah yang bersifat multiobjective (ada banyak tujuan yang ingin dicapai) dan multicriteria (ada banyak kriteria untuk mencapai tujuan). Melalui metode Weighted Product (WP) perusahaan dapat menentukan 
INDEXIA: Informatic and Computational Intelegent Journal

Amirul Aziz, Harunur Rosyid

Sistem Pendukung Keputusan Insentif Kompensasi Berdasarkan Kinerja Karyawan Dengan Metode Weighted Product

Di Pt 007 Group

sendiri bobot kepentingan dari masing-masing kriteria. Maka diperlukan sistem program aplikasi infomasi penggajian, agar dapat membantu pengolahan data yang awalnya perhitungan manual dari excel kemudian dicatat di kertas kecil dimasukkan ke amplop beserta uang gajinya jadi ke print out otomatis dari progam dan bisa dilihat sendiri rincian yang lebih detail dengan cara login di aplikasi system penggajian.

Pengembangan sistem keputusan yang akan dilakukan pada penelitian ini, menggunakan metode Weighted Product. Teknik Weighted Product adalah sebuah metode dari Multiple Attribute Decision Making (MADM). MADM adalah suatu metode yang digunakan untuk mencari alternatif optimal dari sejumlah alternatif dengan kriteria tertentu. Inti dari MADM adalah menentukan nilai bobot untuk setiap atribut, kemudian dilanjutkan dengan proses perankingan yang akan menyeleksi alternatif yang sudah diberikan. Sehingga penggunaan metode ini menjadi salah satu solusi untuk menentukan besaran gaji berdasarkan kinerja. Maka dari itu, penulis melakukan penelitian yang berjudul "Sistem Pendukung Keputusan Insentif Kompensasi Berdasarkan Kinerja Karyawan dengan Metode Weight Product di PT 007 Group".

\section{LANDASAN TEORI}

\subsection{Pengertian Weighted Product}

Metode Weighted Product adalah sebuah metode dari Multiple Attribute Decision Making (MADM). MADM adalah suatu metode yang digunakan untuk mencari alternatif optimal dari sejumlah alternatif dengan kriteria tertentu. Inti dari MADM adalah menentukan nilai bobot untuk setiap atribut, kemudian dilanjutkan dengan proses perankingan yang akan menyeleksi alternatif yang sudah diberikan.

Weighted Product(WP) merupakan salah satu metode yang digunakan untuk menyelesaikan masalah MADM. WP adalah suatu metode yang menggunakan perkalian untuk menghubungkan rating atribut, di mana rating setiap atribut harus dipangkatkan dulu dengan bobot yang bersangkutan. Proses ini sama halnya dengan proses normalisasi. Preferensi untuk alternatif $\mathrm{Ai}$ diberikan sebagai berikut:

$$
S_{i}=\prod_{j=1}^{n} X_{i j} w_{j}
$$

Dimana :

$\mathrm{S}=$ menyatakan preferensi alternatif dianalogikan sebagai vektor $S$

$\mathrm{X}=$ menyatakan nilai kriteria

$\mathrm{W}=$ menyatakan bobot kriteria

$\mathrm{i}=$ menyatakan alternatif

$\mathrm{j}=$ menyatakan kriteria

$\mathrm{n}=$ menyatakan banyaknya kriteria

$\Sigma \mathrm{Wj}=1$.

$W j$ adalah pangkat bernilai positif untuk atribut keuntungan, dan bernilai negatif untuk atribut biaya. Preferensi relatif dari setiap alternatif diberikan sebagai berikut :

$$
V i=\frac{\prod_{j=1}^{n} X_{i j} w_{j}}{\prod_{j=1}^{n} X_{i j *} w_{j}}
$$

Dimana :

$\mathrm{V}=$ menyatakan Preferensi alternatif dianalogikan sebagai vektor $\mathrm{V}$

$\mathrm{X}=$ menyatakan nilai kriteria

$\mathrm{W}=$ menyatakan bobot kriteria

$\mathrm{i}=$ menyatakan alternatif

$\mathrm{j}=$ menyatakan kriteria

$\mathrm{n}=$ menyatakan banyaknya kriteria

* = menyatakan banyaknya kriteria yang telah dinilai pada vektor $S$

\subsection{Algoritma Metode Weighted Product}

Secara umum langkah-langkah yang harus dilakukan dalam menggunakan Weighted Productuntuk pemecahan suatu masalah yaitu :

1. Menentukan bobot preferensi dari setiap kriteria (W).

2. Mengalikan seluruh atribut sebuah alternatif dengan bobot sebagai pangkat positif untuk atribut manfaat 
INDEXIA: Informatic and Computational Intelegent Journal

Amirul Aziz, Harunur Rosyid

Sistem Pendukung Keputusan Insentif Kompensasi Berdasarkan Kinerja Karyawan Dengan Metode Weighted Product Di Pt 007 Group

dan bobot berfungsi sebagai pangkat negatif pada atribut biaya.

3. Hasil perkalian dijumlahkan untuk menghasilkan nilai pada setiap alternatif $(\mathrm{S})$.

4. Mencari nilai setiap alternatif (V) dengan membagi nilai alternatif (S) dengan jumlah total alternatif (S).Alternatif (V) dengan nilai tertinggi menjadi alternatif terbaik

\section{III.ANALISIS DAN PERANCANGAN SISTEM}

\subsection{Analisis Sistem}

Proses pemilihan insentif kompensasi di PT 007 Group dilakukan dengan penggunaan media perhitungan yang terbatas dan banyaknya karyawan terbaik dalam proses perhitungan dapat menghambat dalam proses pemilihan karyawan terbaik, karena proses perhitungan masih dilakukan dengan menggunakan excel yang kurang efektif dalam perhitungannya. Tahapan tersebut mengacu dari ketentuan SDM diantaranya adalah Kinerja, lama bekerja, dan absensi. Dimana masing masing kriteria karyawan dan proses perhitungan telah ditentukan oleh SDM.

Maka diperlukan suatu sistem pendukung keputusan yang dapat memudahkan bagian SDM dalam proses pemilihan insentif karyawan dan dapat menghitung segala kriteria yang mendukung pengambilan keputusan pemilihan karyawan secara cepat dan akurat.

\subsection{Hasil Analisis}

Hasil dari analisa penelitian didapatkan datadata untuk proses pembuatan Sistem Pendukung Keputusan Insentif Kompensasi Berdasarkan Kinerja Karyawan dengan Metode Weight Product di PT 007 Group sebagai pendukung keputusan. Kriteria yang digunakan dalam pengambilan keputusan antara lain : kinerja, lama bekerja, dan absensi. Sebagai obyek dalam penelitian ini digunakan data karyawan dengan inputan keseluruhan kriteria. Dari analisa sistem yang telah dilakukan dapat disimpulkan sebagai berikut :
1. Proses development atau pengembangan sistem merupakan pembuatan sistem yang baru untuk menggatikan sistem yang telah ada, memperbaikinya baik sedikit ataupun keseluruhan dari sistem sehingga hasil yang didapatkan sesuai dan optimal.

2. Deskripsi sistem merupakan gambaran Sistem Pendukung Keputusan Insentif Kompensasi Berdasarkan Kinerja Karyawan dengan Metode Weight Product di PT 007 Group berdasarkan kinerja, absensi, dan lama bekerja karyawan.

3. Ketidak sengajaaan kesalahan pada proses inputan pada kriteria dari Sistem Pendukung Keputusan Insentif Kompensasi Berdasarkan Kinerja Karyawan dengan Metode Weight Product di PT 007 Groupkepada karyawan menyebabkan kebenaran data kurang terjamin, file-file yang kurang teratur, dan kurang efektifnya waktu

Diagram alir sistem penentuan insentif kinerja karyawan ditunjukkan pada berikut :

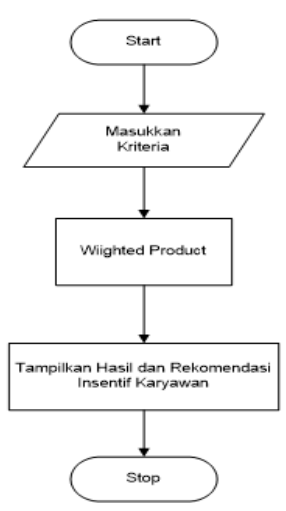

Gambar 3.1 Diagram Alir Sistem Penentuan Insentif Karyawan

Gambar 3.1 menjelaskan tahap analisis yang dimulai dengan memasukkan pelaian kinerja, absensi, dan lama kerja karyawan. Kemudian sistem akan memulai pengelompokkan jurusan metode Weigted Product. Setelah proses selesai 
INDEXIA: Informatic and Computational Intelegent Journal

Amirul Aziz, Harunur Rosyid

Sistem Pendukung Keputusan Insentif Kompensasi Berdasarkan Kinerja Karyawan Dengan Metode Weighted Product

Di Pt 007 Group

maka sistem akan menampilkan hasil dan rekomendasi insentif karyawan.

Berikut merupakan diagram alir perhitungan metode Triple Exponential Smoothing (Brown) :

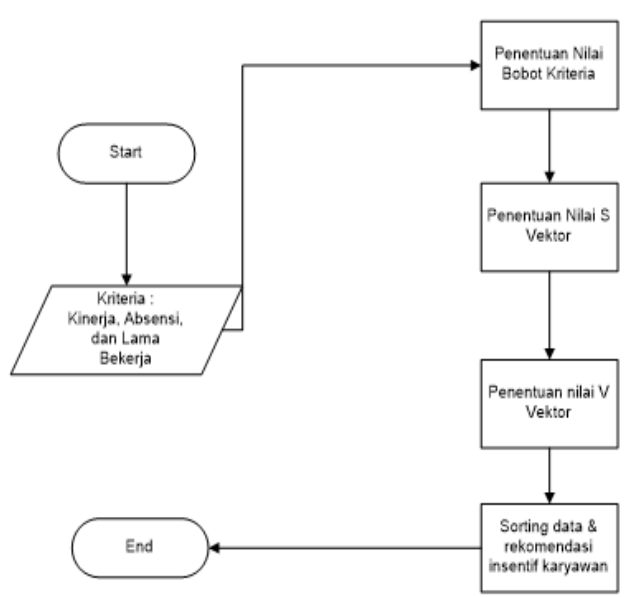

Gambar 3.2 Flowchart Proses Perhitungan Metode Weighted Product

\subsection{Diagram Konteks}

Diagram konteks merupakan diagram yang menunjukkan sebuah proses tunggal dalam sistem yang berhubungan langsung dengan semua entitas eksternal sistem.

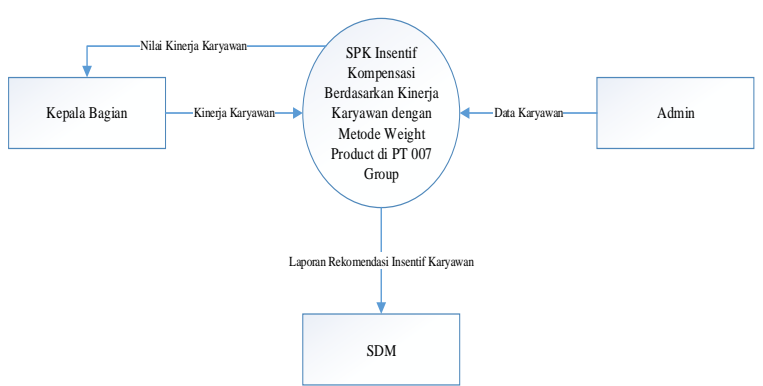

Gambar 3.3 Rancangan Context Diagram Sistem

Admin merupakan pihak yangakan menginputkan data kriteria, bobot kriteria dan data karyawan, hasil dari inputan admin akan diberikan kepada pihak SDM.

Admin memasukkan data kriteria berupa data karyawan, absensi, lama bekerja, dan kinerja. Setelah itu data akan dihitung oleh sistem menggunakan metode Weigted Product dan menghasilkan data sorting nilai V Vektor. Hasil output berupa laporanrekomendasi insentif karyawan dan diberikan kepada pihak SDM.

juga memperoleh info mengenai jumlah penjualan beras, serta mendapatkan hasil prediksi. Sedangkan Pemilik usaha merupakan pihak yang dapat melihat laporan prediksi penjualan beras.

\subsection{Diagram Berjenjang}

Diagram berjenjang sangat diperlukan dalam perancangan semua proses yang ada. diagram berjenjang merupakan penggunaan awal dalam menggambarkan Data Flow Diagram (DFD) ke level - level lebih bawah lagi.

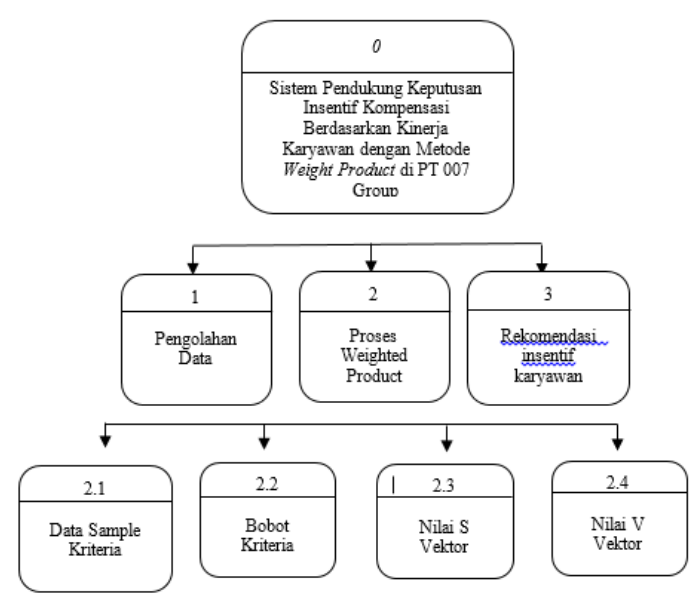

Gambar 3.4 Diagram Berjenjang Sistem Penentuan insentif karyawan

Diagram berjenjang sangat diperlukan dalam perancangan semua proses yang ada. diagram berjenjang merupakan penggunaan awal dalam menggambarkan Data Flow Diagram (DFD) ke level-level lebih bawah lagi Top Level : Sistem Pendukung Keputusan Insentif Kompensasi Berdasarkan Kinerja Karyawan dengan Metode Weight Product di PT 007 Group.

Level 0

: 1. Pengolahan Data

2. Proses Weighted Product

3. Rekomendasi insentif karyawan

Level 1 : Proses 2 : Proses Weighted Product 2.1 Data Sample Kriteria

2.2 Bobot Kriteria

2.3 Nilai S Vektor

2.4 Nilai V Vektor 
INDEXIA: Informatic and Computational Intelegent Journal

Amirul Aziz, Harunur Rosyid

Sistem Pendukung Keputusan Insentif Kompensasi Berdasarkan Kinerja Karyawan Dengan Metode Weighted Product

Di Pt 007 Group

\subsection{Data Flow Diagram (DFD) Level 0}

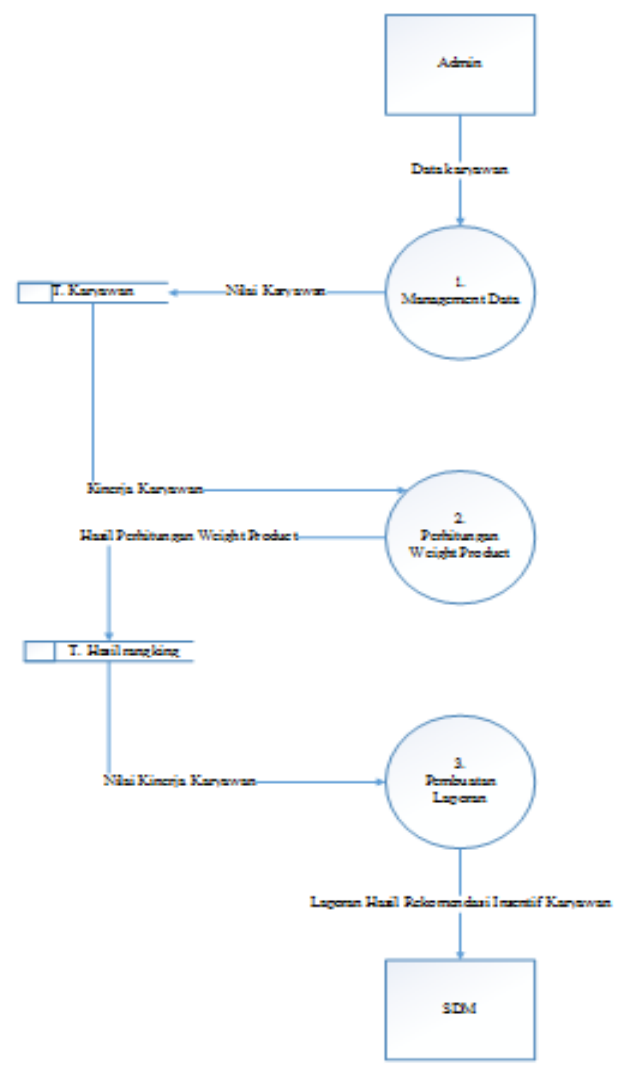

Gambar 3.5 DFD Level 1 Sistem Penentuan insentif karyawan

1. Datakriteria berupa data karyawan, kinerja, lama bekerja, dan absensiyang diinputkan oleh admin diproses pada proses pengolahan datakemudian dari inputan tersebut akan menghasilkan bobot kriteriayang disimpan pada basisdata kriteria.

2. Dari basis data kriteria menghasilkan Nilai Bobot Kriteria, kemudian hasil tersebut di proses perhitungan Weighted Product dan menghasilkan keluaran nilai V Vektor.

3. Dari proses rekomendasi insentif karyawanakan menghasilkan outputan berupa laporan rekomendasi insentif karyawanyang akan disampaikan oleh pihak SDM.

\subsection{Data Flow Diagram (DFD) Level 1}

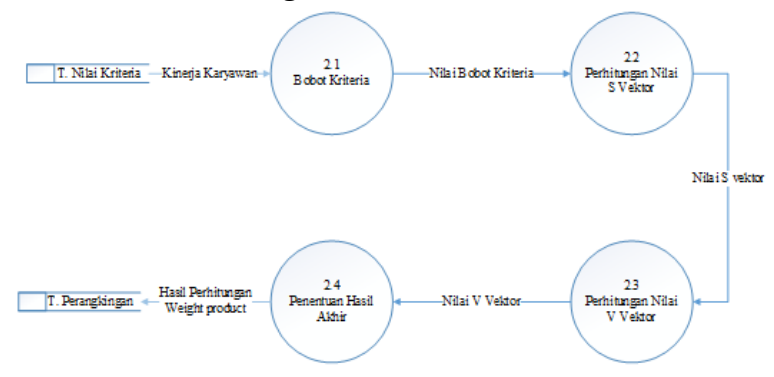

Gambar 3.6 DFD Level 2 Sistem Penentuan insentif karyawan

1. Data sample kriteria mengambil data dari Basis data kriteria berupa kriteria. Lalu dari proses ini menghasilkan detail data kriteria.

2. Proses bobot kriteria mengambil data dari data kriteria karyawan yang didapatkan dari pihak SDM dari proses ini menghasilkan nilai bobot kriteria yang dijadikan untuk perhitungan nilai $\mathrm{S}$ vektor.

3. Proses perhitungan nilai $\mathrm{S}$ vektor dengan cara menggambil data dari nilai bobot kriteria.Pada proses ini akan menghasilkan sebuah nilai S vektor yang digunakan untuk perhitungan nilai $\mathrm{V}$ vektor.

4. Proses perhitungan nilai $\mathrm{V}$ vektor mengambil data hasil dari perhitungan nilai $S$ vektor. Lalu pada proses menghasilkan nilai $\mathrm{V}$ vektor yang akan disorting sehingga menghasilkan hasil akhir sebagai rekomendasi insentif karyawan.

5. Proses hasil akhir mengambil data dari hasil Nilai V Vektor yang sudah disorting, kemudian menghasilkan hasil akhir berupa rekomendasi karyawan.

IV. IMPLEMENTASI DAN PENGUJIAN SISTEM

4.1 Implementasi Sistem

4.1.1 Halaman Login 
INDEXIA: Informatic and Computational Intelegent Journal

Amirul Aziz, Harunur Rosyid

Sistem Pendukung Keputusan Insentif Kompensasi Berdasarkan Kinerja Karyawan Dengan Metode Weighted Product

Di Pt 007 Group

Login merupakan form pertama kali yang muncul saat user menjalankan sistem, Pada form login yang harus diisi yaitu username dan password. Untuk dapat mengakses menu-menu yang terdapat pada hak akses user maka user harus melakukan login terlebih dahulu kedalam sistem menggunakan username dan password yang sudah tersimpan di database

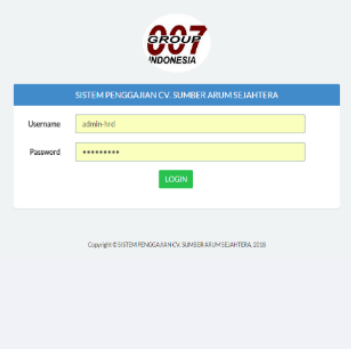

Gambar 4.1 Halaman Login Sistem Pendukung Keputusan Insentif Kompensasi Karyawan

\subsubsection{Halaman Home}

Setelah berhasil melakukan login ke sistem, maka akan muncul tampilan awal seperti Gambar 4.2 sebagai berikut:

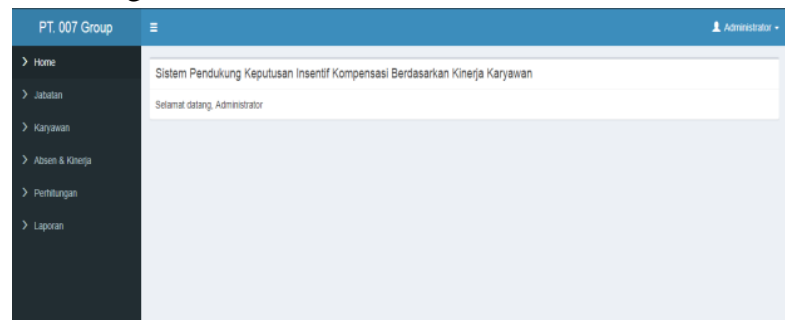

Gambar 4.2 Halaman Home Sistem Pendukung

Keputusan Insentif Kompensasi Karyawan

\subsubsection{Halaman Jabatan}

Halaman jabatan menampilkan data jabatan. Admin mempunyai hak akses dalam menambah, merubah dan menghapus data jabatan pada sistem lihat pada Gambar 4.3 berikut

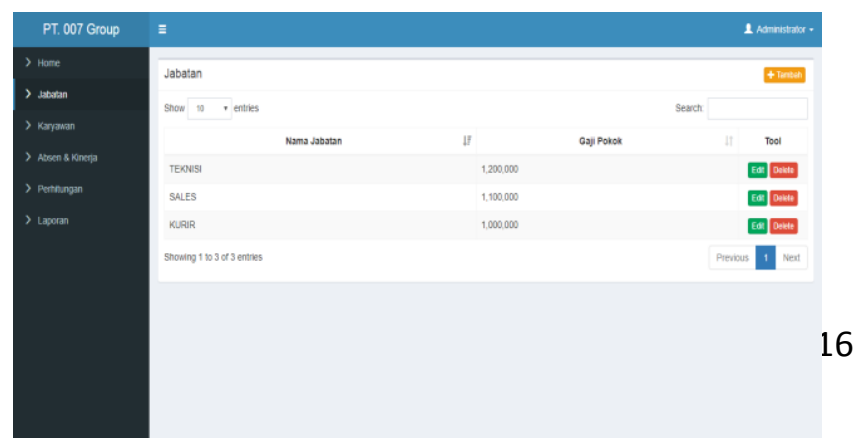

Gambar 4.3 Halaman Data Jabatan.

\begin{tabular}{l} 
Tambah Jabatan \\
Nama Jabatan: \\
\hline Gaji Pokok: \\
\hline \\
\\
\hline Simpan $\times$ Tutup
\end{tabular}

Gambar 4.4 Halaman Tambah Data Jabatan.

\subsubsection{Halaman Karyawan}

a. Data Karyawan

Gambar 4.5 menjelaskan tentang form Data Karyawan



Gambar 4.5 Halaman Data Karyawan

\section{b. Tambah Karyawan}

Form tambah karyawan digunakan untuk menambahkan karyawan. Admin mempunyai hak akses dalam menambah, merubah dan menghapus data karyawan lihat pada Gambar 4.6.

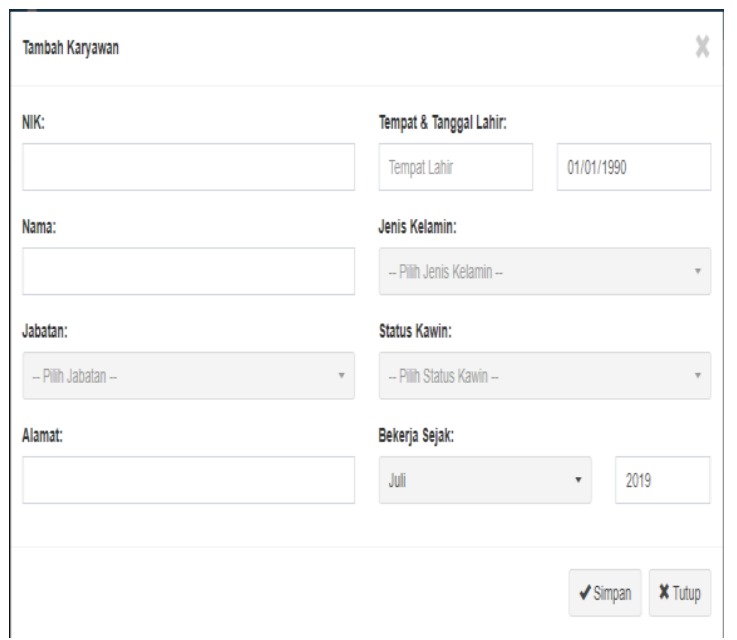


INDEXIA: Informatic and Computational Intelegent Journal

Amirul Aziz, Harunur Rosyid

Sistem Pendukung Keputusan Insentif Kompensasi Berdasarkan Kinerja Karyawan Dengan Metode Weighted Product Di Pt 007 Group

Gambar 4.6 Halaman Tambah Karyawan

\subsubsection{Halaman Absen \& Kinerja}

\section{a. Data Absen \& Kinerja}

Gambar 4.7 menjelaskan tentang form Absen \& Kinerja. Admin mempunyai hak akses dalam menambah, merubah dan menghapus data absen \& kinerja pada sistem lihat pada Gambar 4.7



Gambar 4.7 Halaman Absen \& Kinerja

\section{b. Data Tambah Absen \& Kinerja}

Gambar 4.8 menjelaskan tentang form tambah data absen \& kinerja digunakan untuk menambahkan jumlah data absen dan kinerja.

\begin{tabular}{l} 
Tambah Absen \& Kinerja \\
Karyawan: \\
\hline - Pilih Karyawan - \\
Periode: \\
\hline Juli \\
Absensi: \\
\hline Kinerja:
\end{tabular}

Gambar 4.8 Halaman Tambah Absen \& Kinerja

\subsubsection{Perhitungan}

\section{a. Halaman Perhitungan Pegawai Teknisi}

Gambar 4.9 menjelaskan tentang perhitungan teknisi digunakan untuk melihat Pegawai yang mendapatkan Insentif Kompensasi



Gambar 4.9 Halaman Perhitungan Pegawai Teknisi



\begin{tabular}{|c|c|c|c|c|c|c|c|c|c|c|}
\hline \\
\hline \multirow[b]{2}{*}{ Nama Pegawai } & \multirow[b]{2}{*}{ Jabatan } & \multicolumn{3}{|c|}{ Kiteria } & \multicolumn{3}{|c|}{ s } & \multirow[b]{2}{*}{ Total S } & \multirow[b]{2}{*}{ v } & \multirow[b]{2}{*}{ Peringhkat } \\
\hline & & Absen & Kineja & Lana Kerja & Absen & Kineja & Lama Keja & & & \\
\hline DERI PPASETYY & TENASI & 23 & 200,000 & 15 & 02708 & 1617195 & 0.658 & 27.824 & 0.2628 & 1 \\
\hline 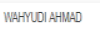 & TENASI & 25 & 1250000 & 26 & 02615 & 1329574 & 05910 & 202027 & 0.1904 & 2 \\
\hline IMAMFARISN & TENNSI & 25 & 125,000 & 29 & 02615 & 1329574 & 0.5705 & 19.8833 & 0.1870 & 3 \\
\hline EROODDIK & TEKNSI & 20 & 95, 000 & 26 & 02870 & 118.5999 & 0.5910 & 197755 & 0.1864 & \\
\hline KHORUL AWVAR & TENNSI & 25 & 1000000 & 26 & 02615 & 121.1528 & 0.5910 & 18490 & 0.1735 & . \\
\hline
\end{tabular}


INDEXIA: Informatic and Computational Intelegent Journal

Amirul Aziz, Harunur Rosyid

Sistem Pendukung Keputusan Insentif Kompensasi Berdasarkan Kinerja Karyawan Dengan Metode Weighted Product

Di Pt 007 Group

Gambar 4.10 Hasil Perhitungan Akhir Data

Pegawai Teknisi

\section{a. Halaman Perhitungan Pegawai Sales}

Gambar 4.11 menjelaskan tentang perhitungan sales digunakan untuk melihat karyawan yang mendapatkan Insentif Kompensasi

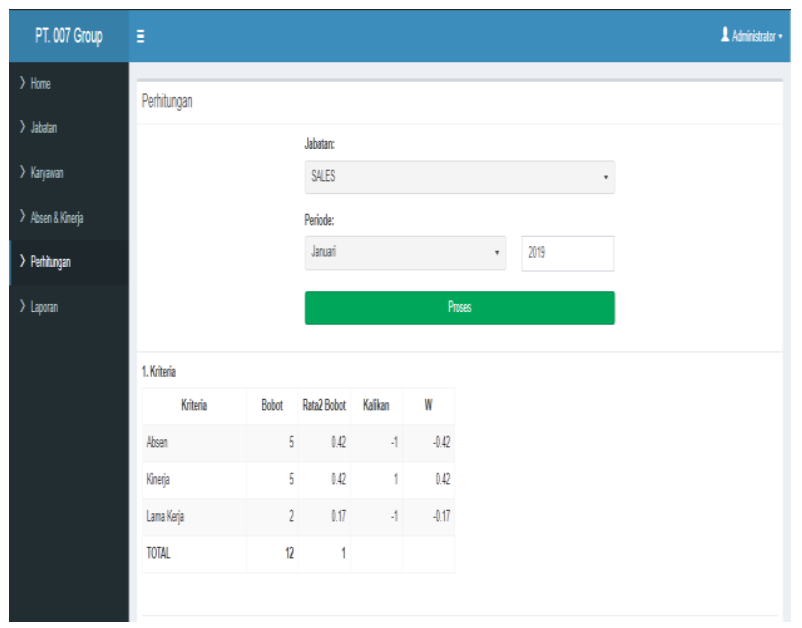

Gambar 4.11 Halaman Perhitungan Pegawai Sales

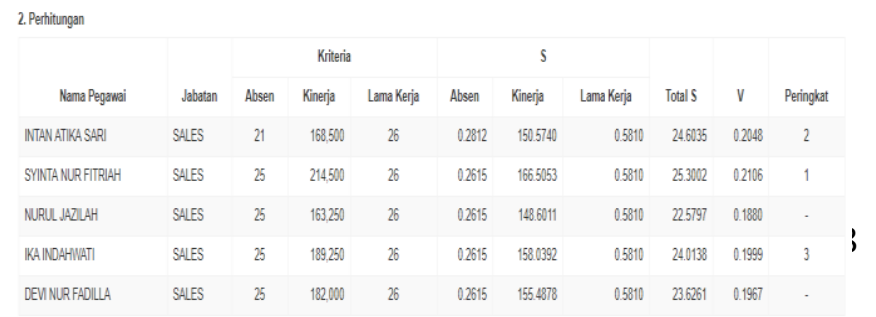

3. Uuskan Berdasarakan Peringke

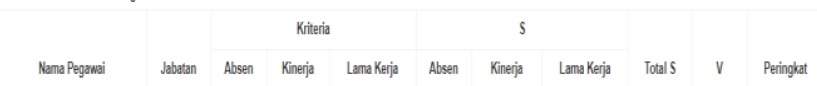

$$
\begin{aligned}
& \begin{array}{llllllllll}
\text { SYINTANRPFTRMH } & \text { SALES } & 25 & 214500 & 26 & 02615 & 1665553 & 0.5810 & 253002 & 02106
\end{array} \\
& \begin{array}{llllllllll}
\text { INTANATKA SAPI } & \text { SALES } & 21 & 166.500 & 26 & 02812 & 150.5740 & 0.5810 & 246035 & 02048
\end{array} \\
& \begin{array}{llllllllll}
\text { IKA NOAHVATI SALS } & 25 & 1892,250 & 26 & 02615 & 1580032 & 0.5810 & 240138 & 0.1909
\end{array}
\end{aligned}
$$

Gambar 4.12 Hasil Perhitungan Akhir Pegawai Sales

\section{a. Halaman Perhitungan Pegawai Kurir}

Gambar 4.13 menjelaskan tentang perhitungan kurir digunakan untuk melihat karyawan yang mendapatkan Insentif Kompensasi

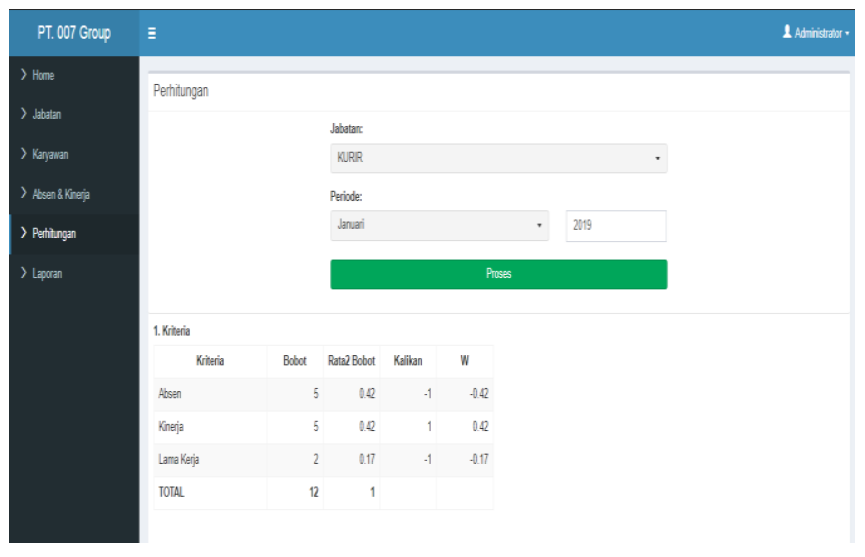

Gambar 4.13 Halaman Perhitungan Pegawai Kurir 
INDEXIA: Informatic and Computational Intelegent Journal

Amirul Aziz, Harunur Rosyid

Sistem Pendukung Keputusan Insentif Kompensasi Berdasarkan Kinerja Karyawan Dengan Metode Weighted Product

Di Pt 007 Group
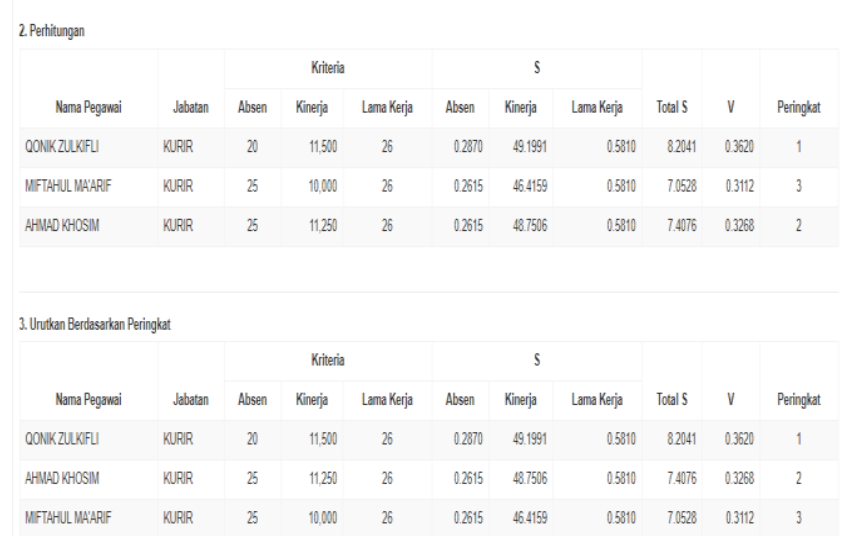

Hasil perhitungan berhasil disimpan di Laporan.

Gambar 4.14 Hasil Perhitungan Akhir Pegawai Kurir

\subsubsection{Halaman Laporan}

Halaman ini digunakan untuk menampilkan laporan dari hasil Sistem Pendukung Keputusan Insentif Kompensasi Karyawan. Hasil laporan bisa diakses Admin dan Manager. Hasil laporan dapat dilihat pada Gambar 4.15 sebagai berikut :



Gambar 4.15 Halaman Laporan

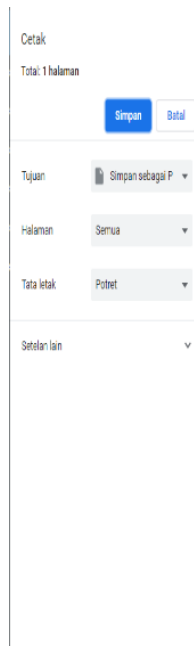

4.2 Analisa Hasil Pengujian Sistem

Untuk Analisa hasil pengujian sistem yakni menggunakan data karyawan di Pt 007 Group.

\subsubsection{Penentuan Penerima Bonus Bagian Teknisi}

Tabel 4.1 Data Pegawai Teknisi

\begin{tabular}{|c|c|c|c|c|c|c|c|c|c|c|c|}
\hline \multirow{2}{*}{ Nama Pegawai } & \multirow{2}{*}{ Jabatan- } & \multicolumn{3}{|c|}{ Kriteria } & \multicolumn{3}{|c|}{ Kiteria } & \multicolumn{3}{|c|}{ s } & \multirow{2}{*}{ Totals } \\
\hline & & Absen & kinerja & Lama Kerja & Absen & kinerja & Lama Kerja & Absen & kinerja & Lama Keja & \\
\hline IMAM FARISIN & 1 & 25 & 125000 & 29 & 25 & 125000 & 29 & 0,2615 & 132,9574 & 0,5705 & 19,8383 \\
\hline DERI PRASETYO & 1 & 23 & 200000 & 15 & 23 & 200000 & 15 & 0,2708 & 161,7195 & 0,6358 & 27,8844 \\
\hline KHOIRULANWAR & 1 & 25 & 100000 & 26 & 25 & 100000 & 26 & 0,2615 & 121,1528 & 0,5810 & 18,4090 \\
\hline ERIQDIDKK & 1 & 20 & 95000 & 26 & 20 & 95000 & 26 & 0,2870 & 118,5909 & 0,5810 & 19,7755 \\
\hline WAHYUDI AHMAD & 1 & 25 & 125000 & 26 & 25 & 125000 & 26 & 0,2615 & 132,9574 & 0,5810 & 20,2027 \\
\hline INTAN ATIKA SARI & 2 & 21 & 168500 & 26 & . & . & . & . & . & . & . \\
\hline SYINTA NUR FTTRAH & 2 & 25 & 214500 & 26 & . & . & . & . & . & . & . \\
\hline NURUL.JAZLLAH & 2 & 25 & 163250 & 26 & . & . & . & . & . & . & . \\
\hline IKA INDAHWATI & 2 & 25 & 189250 & 26 & . & . & . & . & . & . & . \\
\hline DEVI NUR FADILAA & 2 & 25 & 182000 & 26 & . & . & . & - & . & . & . \\
\hline QONKKZULKFIJ & 3 & 20 & 11500 & 26 & . & . & . & $\cdot$ & . & . & . \\
\hline MFAAHUL Ma'ARIF & 3 & 25 & 10000 & 26 & . & . & . & . & . & . & . \\
\hline \multirow[t]{2}{*}{ AHMAD KHOSIM } & 3 & 25 & 11250 & 26 & . & . & . & . & . & . & . \\
\hline & & & & & & & & & & & 106,10976 \\
\hline
\end{tabular}

Dari tabel diatas Nilai tertinggi kemudian di hitung dengan menggunakan metode Waighted Product dengan perhitungan menentukan Nilai V. maka dari hasil perhitungan itu nilai akan otomatis terangking oleh sistem sebagai berikut:

Tabel 4.2 Pegawai Teknisi Yang Terpilih

Mendapatkan Bonus

\begin{tabular}{|c|c|c|c|c|c|c|l|}
\hline \multirow{2}{*}{$\begin{array}{c}\text { Nama } \\
\text { Pegawai }\end{array}$} & \multirow{2}{*}{ Jabatan } & \multicolumn{3}{|c|}{$\mathrm{S}$} & \multirow{2}{*}{ Total S } & $\mathrm{V}$ & Peringkat \\
\cline { 3 - 6 } & & Absen & kinerja & $\begin{array}{c}\text { Lama } \\
\text { Kerja }\end{array}$ & & \\
\hline $\begin{array}{c}\text { IMAM } \\
\text { FARISIN }\end{array}$ & 1 & 0,2615 & 132,9574 & 0,5705 & 19,8383 & 0,1870 & 3 \\
\hline $\begin{array}{c}\text { DERI } \\
\text { PRASETYO }\end{array}$ & 1 & 0,2708 & 161,7195 & 0,6368 & 27,8844 & 0,2628 & 1 \\
\hline
\end{tabular}


INDEXIA: Informatic and Computational Intelegent Journal

Amirul Aziz, Harunur Rosyid

Sistem Pendukung Keputusan Insentif Kompensasi Berdasarkan Kinerja Karyawan Dengan Metode Weighted Product Di Pt 007 Group

\begin{tabular}{|c|c|c|c|c|c|c|l|}
\hline $\begin{array}{c}\text { KHOIRUL } \\
\text { ANWAR }\end{array}$ & 1 & 0,2615 & 121,1528 & 0,5810 & 18,4090 & 0,1735 & - \\
\hline ERIQ DIDIK & 1 & 0,2870 & 118,5909 & 0,5810 & 19,7755 & 0,1864 & - \\
\hline $\begin{array}{c}\text { WAHYUDI } \\
\text { AHMAD }\end{array}$ & 1 & 0,2615 & 132,9574 & 0,5810 & 20,2027 & 0,1904 & 2 \\
\hline $\begin{array}{c}\text { INTAN } \\
\text { ATIKA SARI }\end{array}$ & 2 & - & - & - & - & 0 & - \\
\hline $\begin{array}{c}\text { SYINTA } \\
\text { NUR } \\
\text { FITRIAH }\end{array}$ & 2 & - & - & - & - & 0 & - \\
\hline $\begin{array}{c}\text { NURUL } \\
\text { JAZILAH }\end{array}$ & 2 & - & - & - & - & 0 & - \\
\hline $\begin{array}{c}\text { IKA } \\
\text { INDAHWATI }\end{array}$ & 2 & - & - & - & - & 0 & - \\
\hline $\begin{array}{c}\text { DEVI NUR } \\
\text { FADILLA }\end{array}$ & 2 & - & - & - & - & 0 & - \\
\hline $\begin{array}{c}\text { QONIK } \\
\text { ZULKIFLI }\end{array}$ & 3 & - & - & - & - & 0 & - \\
\hline $\begin{array}{c}\text { MIFTAHUL } \\
\text { MA'ARIF }\end{array}$ & 3 & - & - & - & - & 0 & - \\
\hline $\begin{array}{c}\text { AHMAD } \\
\text { KHOSIM }\end{array}$ & 3 & - & - & - & - & 0 & - \\
\hline & & & & 106,10976 & & \\
\hline
\end{tabular}

Dari gambar 4.2 diatas dapat disimpulkan nilai tertinggi diperoleh pegawai dengan nilai terbesar yaitu untuk peringkat $1(0,2628)$, peringkat 2 $(0,1904)$ dan peringkat $3(0,1870)$.

\subsubsection{Penentuan Penerima Bonus Pegawai Sales}

Tabel 4.3 Data Pegawai Sales

\begin{tabular}{|c|c|c|c|c|c|c|c|c|c|c|c|}
\hline \multirow{3}{*}{$\begin{array}{l}\text { Nama Peganai } \\
\text { MAMFARISN }\end{array}$} & \multirow{3}{*}{$\begin{array}{c}\text { Jaboition } \\
1\end{array}$} & \multirow{2}{*}{\multicolumn{3}{|c|}{$\begin{array}{c}\text { Kriteria } \\
\text { Absen kineria Lama Kerja }\end{array}$}} & \multicolumn{3}{|c|}{ Kiteria } & \multicolumn{3}{|c|}{ s } & \multirow{3}{*}{$\begin{array}{c}\text { Totals } \\
\\
\end{array}$} \\
\hline & & & & & \multirow{2}{*}{$\begin{array}{l}\text { Absen } \\
.\end{array}$} & \multirow{2}{*}{ kineria } & \multirow{2}{*}{ Lamalereja } & \multicolumn{2}{|c|}{ Absen kineria } & \multirow{2}{*}{ Lama kerja } & \\
\hline & & & 125000 & 29 & & & & . & . & & \\
\hline DER PRASETY & 1 & & 200000 & 15 & $\cdot$ & . & . & . & . & . & $\cdot$ \\
\hline RHORULANWAR & 1 & & 100000 & 26 & $\cdot$ & . & . & . & . & . & $\cdot$ \\
\hline ERQDDKK & 1 & 20 & 95000 & 26 & $\cdot$ & . & . & . & . & . & . \\
\hline WAHNUD AAMIMAD & 1 & 25 & 125000 & 26 & $\cdot$ & . & . & . & . & . & . \\
\hline INTANATIKASSRI & 2 & & 168500 & 26 & 21 & 168500 & 26 & 0,281239 & 150,5739996 & 0,5009333 & 24,60247 \\
\hline SYNTANUR FTRRAH & 2 & 25 & 21450 & 26 & 25 & 241500 & 26 & 0,261532 & 16655052916 & 0,500933 & 25,300211 \\
\hline NURULLZZLAH & 2 & & 163250 & 26 & 25 & 163250 & 26 & 0,261532 & 148,6011473 & 0,500933 & 22,599705 \\
\hline IRA NDAHWATI & 2 & & 189750 & 26 & 25 & 198950 & 26 & 0,261532 & 1580,0392476 & 0,5099933 & 24013009 \\
\hline DEVI NURFADLLA & 2 & 25 & 182000 & 26 & 25 & 18000 & 26 & 0,261532 & 155,4878333 & 0,5009933 & 23,066126 \\
\hline CONKZULKF. & 3 & 20 & 11500 & 26 & $\cdot$ & . & . & . & . & . & $\cdot$ \\
\hline MFAAHULMA'ARIF & 3 & 25 & 10000 & 26 & $\cdot$ & . & . & . & . & . & $\cdot$ \\
\hline AHMAD KMOSM & 3 & 25 & 11250 & 26 & . & . & . & . & . & . & . \\
\hline
\end{tabular}

Dari tabel diatas Nilai tertinggi kemudian di hitung dengan menggunakan metode Waighted Product dengan perhitungan menentukan Nilai V. maka dari hasil perhitungan itu nilai akan otomatis terangking oleh sistem sebagai berikut:

Tabel 4.4 Pegawai Sales Yang Terpilih Mendapatkan Bonus

\begin{tabular}{|c|c|c|c|c|c|c|c|}
\hline \multirow{2}{*}{ Nama Pegawai } & \multirow{2}{*}{ Jabatan } & \multicolumn{3}{|c|}{$\mathrm{s}$} & \multirow{2}{*}{ Total S } & \multirow{2}{*}{$\mathrm{v}$} & \multirow{2}{*}{ Peringkat } \\
\hline & & Absen & kinerja & $\begin{array}{l}\text { Lama } \\
\text { Kerja }\end{array}$ & & & \\
\hline $\begin{array}{c}\text { IMAM } \\
\text { FARISIN } \\
\end{array}$ & 1 & & - & - & - & 0 & - \\
\hline $\begin{array}{c}\text { DERI } \\
\text { PRASETYO } \\
\end{array}$ & 1 & - & - & . & & 0 & - \\
\hline $\begin{array}{c}\text { KHOIRUL } \\
\text { ANWAR }\end{array}$ & 1 & - & - & - & & 0 & - \\
\hline ERIQ DIDIK & 1 & - & - & - & & 0 & - \\
\hline $\begin{array}{c}\text { WAHYUDI } \\
\text { AHMAD } \\
\end{array}$ & 1 & & & & & 0 & \\
\hline $\begin{array}{c}\text { INTAN } \\
\text { ATIKA SARI }\end{array}$ & 2 & 0,2812 & 150,5739 & 0,5809 & 24,6034 & 0,2048 & 2 \\
\hline $\begin{array}{l}\text { SYINTA NUR } \\
\text { FITRIAH }\end{array}$ & 2 & 0,2615 & 166,5052 & 0,5809 & 25,3002 & 0,2106 & 1 \\
\hline $\begin{array}{c}\text { NURUL } \\
\text { JAZILAH } \\
\end{array}$ & 2 & 0,2615 & 148,6011 & 0.5809 & 22.5797 & 0,1879 & \\
\hline $\begin{array}{c}\text { IKA } \\
\text { INDAHWATI } \\
\end{array}$ & 2 & 0,2615 & 158,0392 & 0,5809 & 24,0138 & 0,1999 & 3 \\
\hline $\begin{array}{c}\text { DEVI NUR } \\
\text { FADILLA } \\
\end{array}$ & 2 & 0,2615 & 155,4878 & 0,5809 & 23,6261 & 0,1966 & \\
\hline $\begin{array}{c}\text { QONIK } \\
\text { ZULKIFLI } \\
\end{array}$ & 3 & - & - & - & - & 0 & - \\
\hline $\begin{array}{l}\text { MIFTAHUL } \\
\text { MA'ARIF }\end{array}$ & 3 & - & - & - & - & 0 & - \\
\hline $\begin{array}{l}\text { AHMAD } \\
\text { KHOSIM } \\
\end{array}$ & 3 & - & - & - & - & 0 & - \\
\hline & & & & & 120,12332 & & \\
\hline
\end{tabular}

Dari gambar 4.4 diatas dapat disimpulkan nilai tertinggi diperoleh pegawai dengan nilai terbesar yaitu untuk peringkat $1(0,2106)$, peringkat 2 $(0,2048)$ dan peringkat $3(0,1999)$.

\subsubsection{Penentuan Penerima Bonus Pegawai Kurir}

Tabel 4.5 Data Pegawai Kurir

\begin{tabular}{|c|c|c|c|c|c|c|c|c|c|c|c|}
\hline \multirow{2}{*}{ Nama Pegawai } & \multirow{2}{*}{ Jabatan } & \multicolumn{3}{|c|}{ Kriteria } & \multicolumn{3}{|c|}{ Kriteria } & \multicolumn{3}{|c|}{ s } & \multirow{2}{*}{ Totals } \\
\hline & & Absen & kinerja & Lama Kerja & Absen & & Lama Kerja & Absen & kinerja & Lama Kerja & \\
\hline IMAM FARISIN & 1 & 25 & 125000 & 29 & . & . & . & . & . & . & . \\
\hline DERI PRASETYO & 1 & 23 & 200000 & 15 & . & . & . & . & . & - & - \\
\hline KHOIRUL ANWAR & 1 & 25 & 100000 & 26 & . & . & . & . & . & . & . \\
\hline ERIQDDIK & 1 & 20 & 95000 & 26 & . & . & . & . & . & . & . \\
\hline WAHYUDI AHMAD & 1 & 25 & 125000 & 26 & . & . & . & . & . & . & - \\
\hline INTAN ATI|KA SARI & 2 & 21 & 168500 & 26 & - & . & - & - & . & . & - \\
\hline SYINTA NUR FITRIAH & 2 & 25 & 214500 & 26 & - & . & - & - & . & - & - \\
\hline NURULJAZZLAH & 2 & 25 & 163250 & 26 & . & - & . & - & . & . & - \\
\hline |KA INDAHWAT| & 2 & 25 & 189250 & 26 & . & . & . & . & . & . & . \\
\hline DEV NUR FADILLA & 2 & 25 & 182000 & 26 & . & . & . & . & . & . & . \\
\hline aONIKZULKKFLI & 3 & 20 & 11500 & 26 & 20 & 11500 & 26 & 0,287014718 & 1849,19913 & 0,580993279 & 8,2041333 \\
\hline MIFAHUL MA'ARIF & 3 & 25 & 10000 & 26 & 25 & 10000 & 26 & 0,261532097 & 9746,41589 & 0,580993279 & 7,0528195 \\
\hline AHMAD KHOSIM & 3 & 25 & 11250 & 26 & 25 & 11250 & 26 & 0,261532097 & 9748,75063 & 0,580993279 & 7,4075795 \\
\hline
\end{tabular}


INDEXIA: Informatic and Computational Intelegent Journal

Amirul Aziz, Harunur Rosyid

Sistem Pendukung Keputusan Insentif Kompensasi Berdasarkan Kinerja Karyawan Dengan Metode Weighted Product

Di Pt 007 Group

maka dari hasil perhitungan itu nilai akan otomatis

terangking oleh sistem sebagai berikut:

Tabel 4.6 Pegawai Kurir Yang Terpilih Mendapatkan

Bonus

\begin{tabular}{|c|c|c|c|c|c|c|c|}
\hline \multirow{2}{*}{$\begin{array}{l}\text { Nama } \\
\text { Pegawai }\end{array}$} & \multirow{2}{*}{$\begin{array}{c}\text { Jabata } \\
\mathrm{n}\end{array}$} & \multicolumn{3}{|c|}{$\mathrm{s}$} & \multirow{2}{*}{ Total S } & \multirow{2}{*}{$\mathrm{v}$} & \multirow{2}{*}{$\underset{\mathrm{t}}{\text { Peringka }}$} \\
\hline & & Absen & kinerja & $\begin{array}{l}\text { Lama } \\
\text { Kerja }\end{array}$ & & & \\
\hline $\begin{array}{c}\text { IMAM } \\
\text { FARISIN }\end{array}$ & 1 & - & - & - & - & 0 & - \\
\hline $\begin{array}{c}\text { DERI } \\
\text { PRASETYO } \\
\end{array}$ & 1 & - & - & - & - & 0 & - \\
\hline $\begin{array}{l}\text { KHOIRUL } \\
\text { ANWARR }\end{array}$ & 1 & & - & - & & 0 & - \\
\hline ERIQ DIDIK & 1 & - & - & - & - & 0 & - \\
\hline $\begin{array}{l}\text { WAHYUDI } \\
\text { AHMAD } \\
\end{array}$ & 1 & & - & & & 0 & - \\
\hline $\begin{array}{c}\text { INTAN } \\
\text { ATIKA SARI }\end{array}$ & 2 & - & - & - & - & 0 & - \\
\hline $\begin{array}{c}\text { SYINTA } \\
\text { NUR } \\
\text { FITRIAH } \\
\end{array}$ & 2 & & 5 & - & & 0 & - \\
\hline $\begin{array}{c}\text { NURUL } \\
\text { JAZILAH }\end{array}$ & 2 &  & - & - & - & 0 & - \\
\hline $\begin{array}{c}\text { IKA } \\
\text { INDAHWAT } \\
\text { I } \\
\end{array}$ & 2 & - & - & - & - & 0 & - \\
\hline $\begin{array}{l}\text { DEVI NUR } \\
\text { FADILLA } \\
\end{array}$ & 2 & - & - & - & - & 0 & - \\
\hline $\begin{array}{c}\text { QONIK } \\
\text { ZULKIFLI } \\
\end{array}$ & 3 & 0,2870 & $\begin{array}{c}49,199 \\
1 \\
\end{array}$ & $\begin{array}{c}0,580 \\
9 \\
\end{array}$ & 8,2041 & 0,3619 & 1 \\
\hline $\begin{array}{l}\text { MIFTAHUL } \\
\text { MA'ARIF }\end{array}$ & 3 & 0,2615 & $\begin{array}{c}46,415 \\
8 \\
\end{array}$ & $\begin{array}{c}0,580 \\
9 \\
\end{array}$ & $\begin{array}{r}7,0528 \\
\end{array}$ & 0,3111 & 3 \\
\hline $\begin{array}{l}\text { AHMAD } \\
\text { KHOSIM } \\
\end{array}$ & 3 & 0,2615 & $\begin{array}{c}48,750 \\
6 \\
\end{array}$ & $\begin{array}{c}0,580 \\
9 \\
\end{array}$ & 7,4075 & 0,3268 & 2 \\
\hline & & & & & & $\begin{array}{l}22,664 \\
5\end{array}$ & \\
\hline
\end{tabular}

Dari tabel 4.6 diatas dapat disimpulkan nilai tertinggi diperoleh pegawai dengan nilai terbesar yaitu untuk peringkat $1(0,3619)$, peringkat 2 $(0,3268)$ dan peringkat $3(0,3111)$.

\subsection{Keberhasilan}

\subsubsection{Perhitungan nilai akhir sistem Pendukung}

\section{Keputusan}

Setelah dilakukan perhitungan dengan menggunakan metode Weighted product untuk menentukan nilai Tertinggi dari masing-masing kriteria kemudian dari nilai-nilai tersebut di hitung kembali untuk menentukan nilai akhir. Berikut tampilan perhitungan nilai akhir:

Tabel 4.7 Keberhasilan

\begin{tabular}{|c|c|c|c|c|c|c|c|c|c|c|}
\hline \multirow{2}{*}{$\begin{array}{c}\text { Nama } \\
\text { Pegawai }\end{array}$} & \multirow[b]{2}{*}{ Jabatan } & \multicolumn{3}{|c|}{$\begin{array}{l}\text { Kriteria } \\
\end{array}$} & \multicolumn{3}{|c|}{ s } & \multirow[b]{2}{*}{ Total S } & \multirow[b]{2}{*}{ v } & \multirow[b]{2}{*}{ Peringkat } \\
\hline & & Absen & \begin{tabular}{|l|} 
kinerja \\
\end{tabular} & \begin{tabular}{|l|} 
Lama \\
Kerja
\end{tabular} & Absen & kinerja & \begin{tabular}{|l|} 
Lama \\
Kerja
\end{tabular} & & & \\
\hline $\begin{array}{l}\text { IMAM } \\
\text { FARISIN }\end{array}$ & 1 & 25 & 125000 & 29 & 0,2615 & 132,9574 & 0,5705 & 19,8383 & 0,0797 & - \\
\hline $\begin{array}{c}\text { DERI } \\
\text { PRASETYO }\end{array}$ & 1 & 23 & 200000 & 15 & 0,2707 & 161,7195 & 0,6367 & 27,88436 & 0,1120 & 1 \\
\hline $\begin{array}{l}\text { KHOIRUL } \\
\text { ANWAR }\end{array}$ & 1 & 25 & 100000 & 26 & 0,2615 & 121,1527 & 0,5809 & 18,4089 & 0,0740 & - \\
\hline ERIQ DIDIK & 1 & 20 & \begin{tabular}{|l|}
95000 \\
\end{tabular} & 26 & 0,2870 & 118,5909 & 0,5809 & \begin{tabular}{|l|}
19,7754 \\
\end{tabular} & 0,0795 & - \\
\hline $\begin{array}{l}\text { WAHYUDI } \\
\text { AHMAD }\end{array}$ & 1 & 25 & 125000 & 26 & 0,2615 & 132,9574 & 0,5809 & 20,2026 & 0,0812 & - \\
\hline $\begin{array}{c}\text { INTAN } \\
\text { ATIKA SARI }\end{array}$ & 2 & 21 & 168500 & 26 & 0,2812 & 150,5739 & 0,5809 & 24,6034 & 0,0988 & 3 \\
\hline $\begin{array}{c}\text { SYINTA } \\
\text { NUR } \\
\text { FITRIAH }\end{array}$ & 2 & 25 & 214500 & 26 & 0,2615 & 166,5052 & 0,5809 & 25,3002 & 0,1016 & 2 \\
\hline $\begin{array}{l}\text { NURUL } \\
\text { JAZILAH }\end{array}$ & 2 & 25 & 163250 & 26 & 0,2615 & 148,6011 & 0,5809 & 22,5797 & 0907 & - \\
\hline $\begin{array}{c}\text { IKA } \\
\text { INDAHWATI }\end{array}$ & 2 & 25 & 189250 & 26 & 0,2615 & 158,0392 & 0,5809 & 24,0138 & 0,0964 & - \\
\hline $\begin{array}{l}\text { DEVI NUR } \\
\text { FADILAA }\end{array}$ & 2 & 25 & 182000 & 26 & 0,2615 & 155,4878 & 0,5809 & 23,6261 & 0949 & - \\
\hline $\begin{array}{c}\text { QONII } \\
\text { ZULKIFLI }\end{array}$ & 3 & 20 & 11500 & 26 & 0,2870 & 49,1991 & 0,5809 & 8,20413 & 0,0329 & - \\
\hline $\begin{array}{l}\text { MIFTAHUL } \\
\text { MA'ARIF }\end{array}$ & 3 & 25 & 10000 & 26 & 0,2615 & 46,4158 & 0,5809 & 7,0528 & 0,0283 & 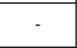 \\
\hline $\begin{array}{l}\text { AHMAD } \\
\text { KHOSIM }\end{array}$ & 3 & 25 & 11250 & 26 & 0,2615 & 48,7506 & 0,5809 & 7,4075 & 0,02976 & - \\
\hline & & & & & & & & 248,8976 & & \\
\hline
\end{tabular}

Dari tabel 4.7, diatas adalah tampilan dari seluruh nilai kriteria calon penerima bonus yang telah melalui proses hitungan dengan metode Weighted product, dapat disimpulkan perolehan Nilai Akhir dari masing-masing Kriteria yang diperoleh. Setelah menampilkan hasil perhitungan nilai akhir masing-masing kriteria kemudian nilai tersebut di jumlahkan untuk memperoleh nilai yang mutlak untuk pemilihan penerima bonus. Hasil pengujian seperti yang terlihat pada tabel 4.9. Dapat disimpulkan bahwa hasil perhitungan tersebut adalah hasil terakhir dari proses pemilihan penerimaan bonus pegawai. Dimana di peroleh peringkat pertama 0,1120 , peringkat kedua 0,1016 dan peringkat ketiga 0,0988 .

\section{KESIMPULAN DAN SARAN}

\subsection{Kesimpulan}

Berdasarkan hasil dari implementasi dan pengujian sistem, maka dalam penelitian tugas akhir ini dapat disimpulkan sebagai berikut:

Sistem ini membantu pihak Kemahasiswaan Human Resourse Development (HRD) untuk menentukan insentif kompensasi berdasarkan kinerja karyawan di PT 007 Group. Karena dapat memberikan hasil perhitungan yang efektif dan akurat dalam proses penentuan bonus pegawai 
INDEXIA: Informatic and Computational Intelegent Journal

Amirul Aziz, Harunur Rosyid

Sistem Pendukung Keputusan Insentif Kompensasi Berdasarkan Kinerja Karyawan Dengan Metode Weighted Product Di Pt 007 Group

\subsection{Saran}

Adapun saran yang dapat diberikan kepada penelitian berikutnya apabila ingin mengembangkan sistem yang telah dibuat ini agar menjadi lebih baik adalah:

1. Untuk segi tampilan dari sistem pendukung keputusan agar lebih menarik lagi.

2. Dalam pengembangan selanjutnya disarankan untuk menggunakan metode lain. Karna pengunaan Metode Weighted Product sangat bergantung pada banyaknya data yang akan di proses untuk menentukan tingkat akurasi tiap penerimaan bonus pegawai.

\section{DAFTAR PUSTAKA}

Oemar Hamalik. (1993). Strategi Belajar Mengajar. Bandung: Mandar Maju

Effendy, Onong Uchjana. 1989. KAMUS KOMUNIKASI. Bandung : PT. Mandar Maju. Hafidiah, Atin., Sumartaya, Dusa. 2003. Sistem Informasi Manajemen Untuk Organisasi Bisnis. Bandung : Kencana Utama.

Edhy Sutanta. 2003. Sistem Informasi Manajemen. Graha Ilmu. Yogyakarta.

Alter, S., 1992, Information Systems a Management Perspective, Addison-Wesley

Jogiyanto. 2001. Analisis \& Desain Sistem Informasi : pendekatan terstruktur teori dan praktek aplikasi bisnis. Andi, Yogyakarta.

Kusrini. 2007. Konsep dan Aplikasi Sistem Pendukung Keputusan. Penerbit Andi, Yogyakarta

Azhar, Kasim. 1995. Teori Pembuatan Keputusan. Jakarta : Fakultas Ekonomi Universitas Indonesia.

Kadarsah, Suryadi, 1998. Sistem Pendukung Keputusan: Suatu Wacana Struktural dan
Implementasi konsep pengambilan keputusan.

Bandung. Remaja Rosdakarya. 